\title{
Removal of chromium (VI) in aqueous solution by oat biomass (Avena sativa)
}

\section{Remoción de cromo (VI) en solución acuosa por biomasa de avena (Avena sativa)}

Nancy Cecilia Pacheco-Castillo ${ }^{1}$, Juan Fernando Cárdenas-González ${ }^{1}$, María de Guadalupe Moctezuma Zarate ${ }^{1}$, Víctor Manuel Martínez-Juárez ${ }^{2}$, Adriana Rodríguez-Pérez ${ }^{1}$, Ismael Acosta-Rodríguez ${ }^{1 *}$

${ }^{1}$ Laboratorio de Micología Experimental, Facultad de Ciencias Químicas, Universidad Autónoma de San Luis Potosí. ${ }^{2}$ Área Académica de Medicina Veterinaria y Zootecnia. Instituto de Ciencias Agropecuarias. Universidad Autónoma del Estado de Hidalgo, México.

*Corresponding author.

E-mail address: iacosta@uaslp.mx (I. Acosta-Rodríguez).

Article history:

Received: 12 December 2016 / Received in revised form: 20 June 2017 / Accepted: 30 June 2017 / Published online: 1 July 2017

https://doi.org/10.29267/mxjb.2017.2.2.196

\begin{abstract}
Chromium (VI) removal capacity in aqueous solution by oat biomass was analyzed by the diphenylcarbazide method. Bioadsorption was evaluated at different $\mathrm{pH}$ values $(1,2,3$ and 4) and at different times. The effect of temperature in the range of $28{ }^{\circ} \mathrm{C}$ to $60{ }^{\circ} \mathrm{C}$ and the removal at different initial $\mathrm{Cr}$ (VI) concentrations of 200 to $1000 \mathrm{mg} / \mathrm{L}$ were also studied. The highest bioadsorption ( $100 \%$ with $100 \mathrm{mg} / \mathrm{L}$ of the metal and $1 \mathrm{~g}$ of biomass) was at 8 $\mathrm{h}$, at $\mathrm{pH}$ of 1.0 and $28{ }^{\circ} \mathrm{C}$. With regard to temperature, the highest removal was to $60{ }^{\circ} \mathrm{C}$, with a $100 \%$ removal at 90 min. Removal was more efficient when higher concentrations of biomass were used (100\%, $3 \mathrm{~h}$ and $5 \mathrm{~g}$ of biomass). Untreated biomass (washed and ground biomass) showed excellent metal removal capacity in situ, $82.6 \%$ and $85.3 \%$ removal in contaminated soil and water, respectively, after 10 days of incubation, using 25 $\mathrm{g}$ of the biomass (100 mL of water). These results show that $\mathrm{Cr}$ (VI) can be removed from industrial wastewater using oat biomass.
\end{abstract}

Keywords: Avena sativa, Biomass, Chromium (VI), Removal. 


\section{RESUMEN}

La capacidad de remoción de Cr (VI) en solución acuosa empleando la biomasa de avena fue analizada por el método de la difenilcarbazida. La bioadsorción fue evaluada a diferentes valores de $\mathrm{pH}(1,2,3$ y 4) y a diferentes tiempos. También se estudió el efecto de la temperatura en el intervalo de $28^{\circ} \mathrm{C}$ hasta $60^{\circ} \mathrm{C}$ y la remoción a diferentes concentraciones iniciales de $\mathrm{Cr}$ (VI) de 200 a 1000 mg/L. La mayor bioadsorción (100\% con $100 \mathrm{mg} / \mathrm{L}$ del metal y $1 \mathrm{~g}$ de biomasa) fue a las $8 \mathrm{~h}$, a pH de 1.0 y $28^{\circ} \mathrm{C}$. La temperatura óptima de remoción $(100 \%)$ fue $60^{\circ} \mathrm{C}$ a los $90 \mathrm{~min}$. La remoción fue más eficiente cuando se emplearon mayores concentraciones de biomasa $(100 \%, 3 \mathrm{~h} \mathrm{y} 5 \mathrm{~g}$ de biomasa). La biomasa no tratada (biomasa lavada y molida) mostró una excelente capacidad de remoción del metal in situ, $82.6 \%$ y $85.3 \%$ de remoción en tierra y agua contaminadas, respectivamente, a los 10 días de incubación, empleando $25 \mathrm{~g}$ de la biomasa $(100 \mathrm{~mL}$ de agua). Estos resultados muestran que el Cr (VI) puede ser eliminado de aguas residuales industriales empleando biomasa de avena.

Palabras clave: Avena sativa, Biomasa, Cromo (VI), Remoción.

\section{INTRODUCTION}

Chromium is regarded as an environmental pollutant due to its wide use in various industrial activities, such as electrolytic plating, leather tanning, explosives manufacturing, etc. The stable forms of chromium in the environment are trivalent ( $\mathrm{Cr}$ (III)) and hexavalent chromium (Cr (VI)). Further, $\mathrm{Cr}$ (VI) is highly soluble, making it mobile in soil and aquatic environments, with consequent toxicity to ecosystems. Chromium in their different forms can be use in the production of steel alloys and other metals chromed, for dyes and pigments, and the preservation of leather and wood. It can also be find naturally in the soil (Gutiérrez-Corona et al., 2016). The primary forms of chromium found in nature are chromium (III) and chromium (VI) and these forms are converted to each other depending on environmental conditions (Ahemad, 2014). $\mathrm{Cr}$ (VI) is consider the most toxic form of chromium, and is usually associated with oxygen as chromates $\left(\mathrm{CrO}_{4}^{-2}\right)$ and dichromates $\left(\mathrm{Cr}_{2} \mathrm{O}_{7}^{-2}\right)$, which due to its high solubility are highly mobile in soil environments and water (Gutiérrez-Corona et al., 2016). Moreover, Cr (III) is in the form of oxides, hydroxides or poorly soluble sulfates, by which it is much less mobile, and there joined organic matter in the soil and aquatic environments (Lofroth \& Ames, 1978). Cr (VI) is a strong oxidizing agent, and in the presence of organic matter is reduced to $\mathrm{Cr}$ (III); this transformation is faster in acidic environments (Dhal et al., 2013). However, high levels of Cr (VI) may exceed the reducing capacity of the environment and thus can persist as a contaminant. It has been established now that various chromium compounds as oxides, chromates and dichromates, are environmental contaminants in water, soil, and industrial effluents (Ahemad, 2014; Watts et al., 2015).

There are studies of many methods for removal of chromium ion present in water industrial waste, for example: ion exchange on resins, coagulation-flocculation, adsorption on activated carbon, reduction, chemical precipitation, sedimentation, etc., which in most cases are expensive or inefficient, especially when the concentration of these ions is very low (Caviedes Rubio et al., 2015). Therefore arise emerging technologies such as biosorption, 
the process of attracting various chemical species by biomass (live or dead), by physicochemical mechanisms as adsorption or ion exchange (Tejada Tovar et al., 2015). Recently, varieties of low cost materials have been studied for their ability to remove $\mathrm{Cr}$ (VI) from aqueous solution and promising results are shown. Among these low cost adsorbents are dead microorganisms, clay minerals, agricultural wastes, industrial wastes and various other low cost materials (Acosta-Rodríguez et. al., 2016; Gutiérrez-Corona et al., 2016; Tejada Tovar et al., 2015). Thus, there is a need to develop or find innovative low cost adsorbents with an affinity towards metal ions for the removal of $\mathrm{Cr}$ (VI) from aqueous solution, which leads to high adsorption capacity (Caviedes Rubio et al., 2015). The objective of this study was to analyze in vitro biosorption of $\mathrm{Cr}$ (VI) by Avena sativa biomass.

\section{MATERIALS AND METHODS}

\subsection{Biosorbent}

The cups of A. sativa oats was obtained from the store offered in the market place Republic, in February 2016, of the capital city of San Luis Potosí, S.L.P. México. The product was ground in blender and stored in amber vials until use.

\subsection{Biosortion studies and determination of hexavalent chromium}

In these studies, was used $1 \mathrm{~g}$ of dried biomass mixed with $100 \mathrm{~mL}$ of trideionized water, containing $100 \mathrm{mg} / \mathrm{L}$ of the metal bearing solution in an Erlenmeyer flask at the desired temperature and $\mathrm{pH}$. The flasks were agitated on a shaking bath Yamato BT-25 model at different times. Samples of $5 \mathrm{~mL}$ were taken at different times and centrifuged at $3000 \mathrm{rpm}$ for 5 min. The supernatant liquid was separated and analyzed for $\mathrm{Cr}$ (VI) ions by a spectrophotometric method employing diphenylcarbazide (Greenberg et al., 1992). The information shown in the results section are the mean from three experiments carried out by triplicate.

\section{RESULTS}

The optimum time and $\mathrm{pH}$ for $\mathrm{Cr}$ (VI) removal for A. sativa biomass was $8 \mathrm{~h}$ and $\mathrm{pH} 1.0$, at constant values of biosorbent dosage $(1 \mathrm{~g} / 100 \mathrm{~mL})$, with an initial metal concentration (100 $\mathrm{mg} / \mathrm{L}$ ), and temperature of $28^{\circ} \mathrm{C}$ (Fig. 1). It was used a $\mathrm{pH}$ meter Corning Pinnacle 530 model and we use nitric acid $1 \mathrm{M}$ to maintain the $\mathrm{pH}$. Adsorption efficiency of $\mathrm{Cr}$ (VI) was observe a maximum at $\mathrm{pH} 1.0$ with the biomass analyzed. As the initial $\mathrm{pH}$ values increased from 1.0 to 4.0 , the removal efficiencies of $\mathrm{Cr}(\mathrm{VI})$ with the biomass decreased from $100 \%$ to $52 \%$, respectively (Fig. 1 ). 


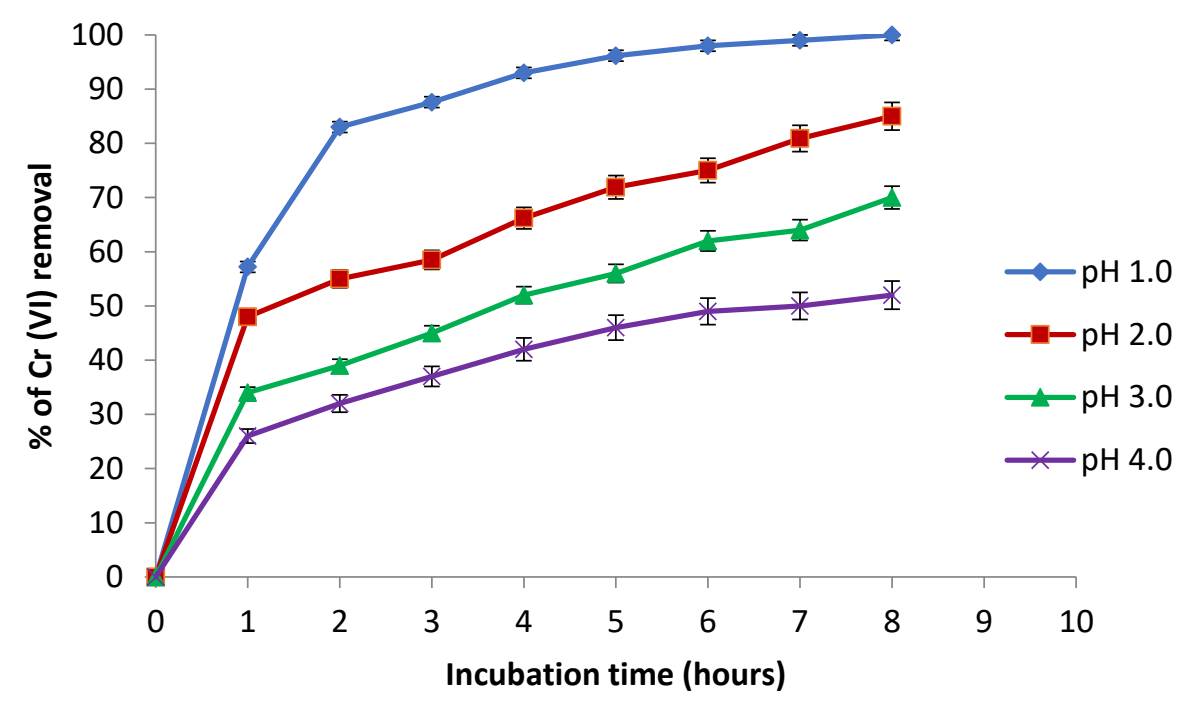

Fig. 1. Effect of incubation time and $\mathrm{pH}$ on chromium (VI) removal by the biomass of $A$. sativa. $100 \mathrm{mg} / \mathrm{L} \mathrm{Cr}(\mathrm{VI}), 100 \mathrm{rpm}, 28^{\circ} \mathrm{C}, 1 \mathrm{~g}$ of biomass.

Temperature was found to be a critical parameter in the bioadsorption of $\mathrm{Cr}$ (VI) (Fig. 2). To maintain constant the temperature in all experiments, we use a shaking bath Yamato BT-25 model. The total removal was observed at $60^{\circ} \mathrm{C}$ with 90 minutes of incubation.

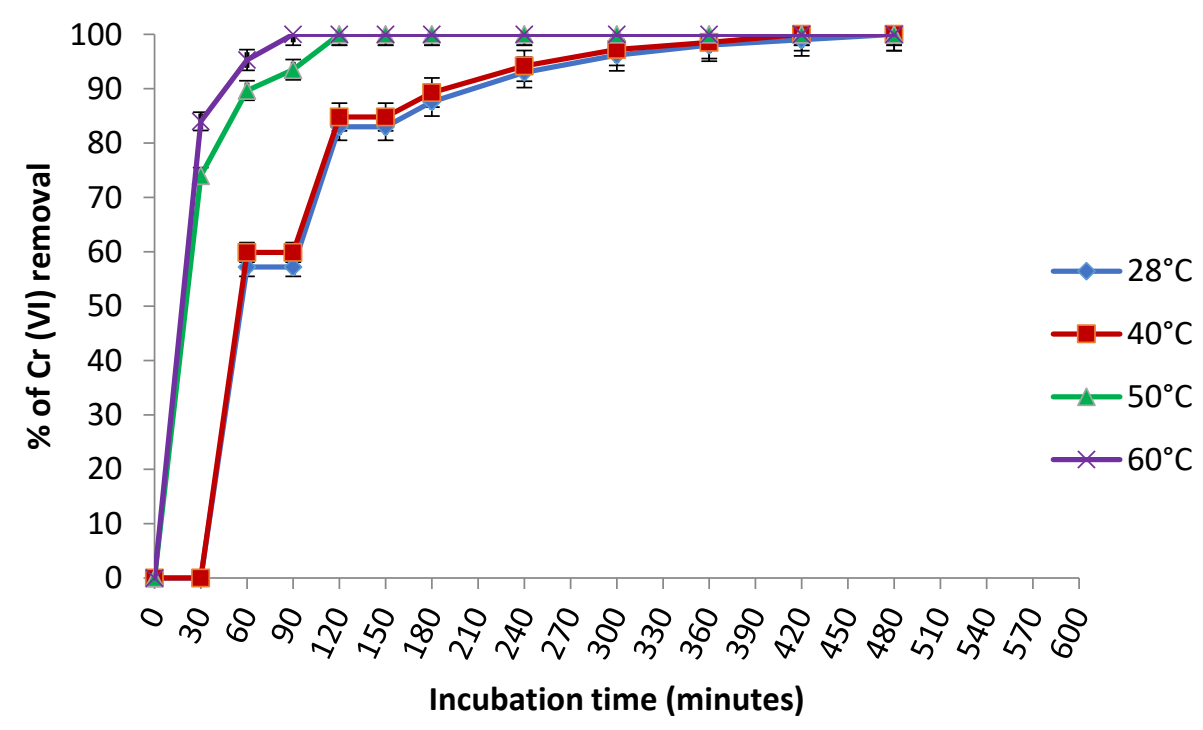

Fig. 2. Effect of temperature on chromium (VI) removal by the biomass of A. sativa. 100 $\mathrm{mg} / \mathrm{L} \mathrm{Cr}(\mathrm{VI}), 100 \mathrm{rpm}, 28^{\circ} \mathrm{C} .1 \mathrm{~g}$ of biomass.

Otherwise, at low metal concentrations $(200 \mathrm{mg} / \mathrm{L})$, we observe the best results for removal, with the biomass analyzed, at $28^{\circ} \mathrm{C}$, respectively (Fig. 3). 


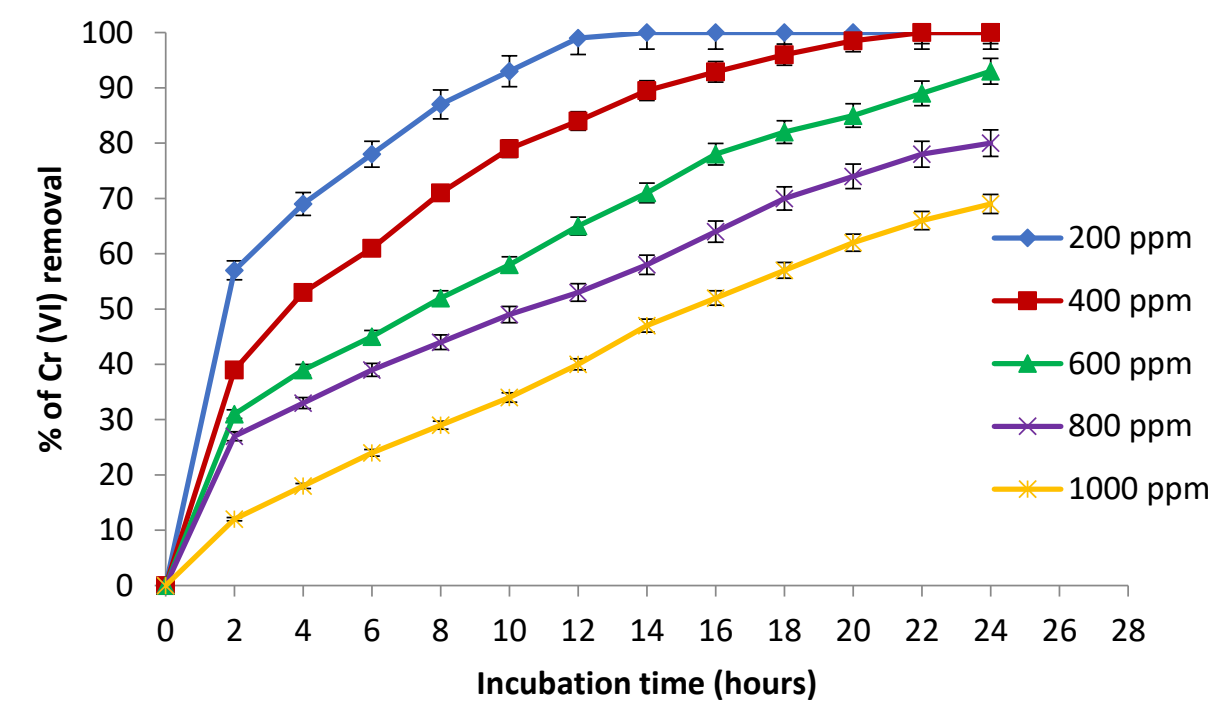

Fig. 3. Effect of initial concentration of metal on chromium (VI) removal by the biomass of A. sativa. $100 \mathrm{rpm}, 28^{\circ} \mathrm{C} .1 \mathrm{~g}$ of biomass.

The influence of biomass concentration on the removal capacity of $\mathrm{Cr}$ (VI) is showed in Fig. 4. If we increase, the amount of biomass it also increases the removal of the metal in solution, with more biosorption sites of the same, because the amount of added biosorbent determines the number of binding sites available for metal biosorption (Cervantes et al., 2001).

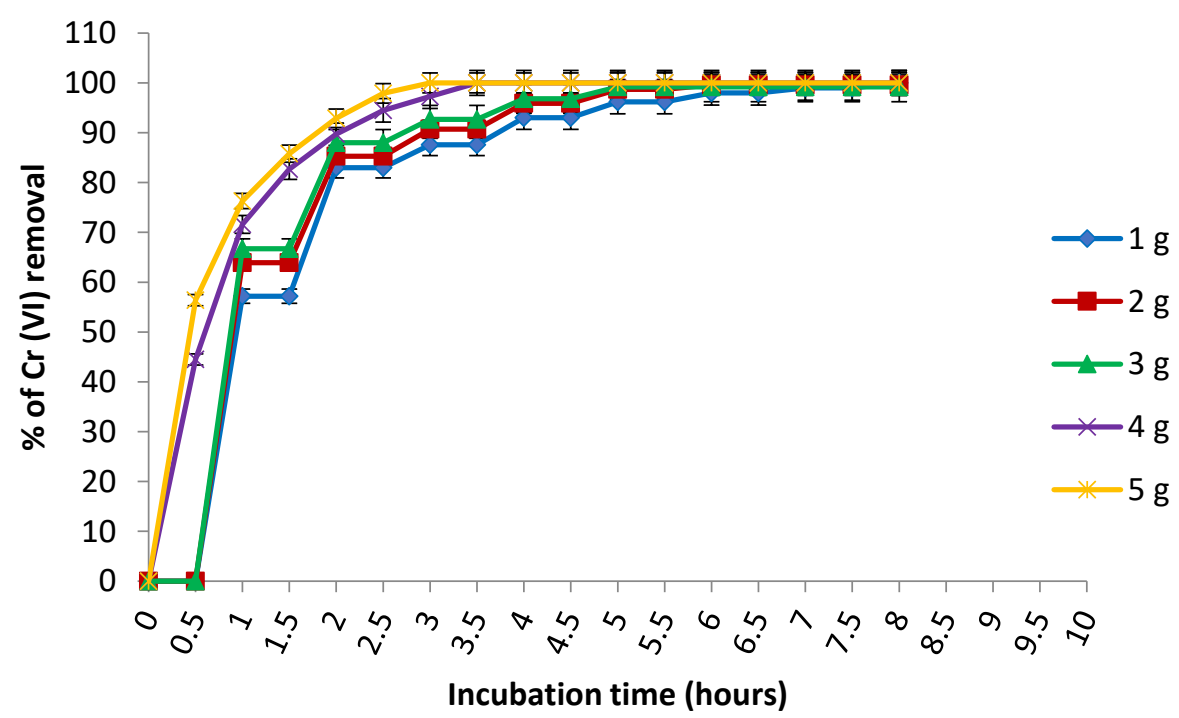

Fig. 4. Effect of biomass concentration on the removal of $100 \mathrm{mg} / \mathrm{L}$ of $\mathrm{Cr}$ (VI) by the biomass of A. sativa. $100 \mathrm{rpm}, 28^{\circ} \mathrm{C}$.

Finally, We adapted a water-phase bioremediation assay to explore possible usefulness of this biomass for eliminating $\mathrm{Cr}$ (VI) from industrial wastes, the biomass (25 g), was incubate with non-sterilized contaminated earth and water containing $297 \mathrm{mg} \mathrm{Cr}(\mathrm{VI}) / \mathrm{g}$, and $200 \mathrm{mg} \mathrm{Cr}(\mathrm{VI}) / \mathrm{L}$, suspended in trideionized water. It was observe that in 10 days of 
incubation with the biomass, the $\mathrm{Cr}$ (VI) concentration of earth and water samples decrease $85.3 \%$ and $82.6 \%$ (Fig. 5), and the decrease level occurred without change significant in total Chromium content during the experiments. In the experiment carried out in the absence of the biomass, the $\mathrm{Cr}$ (VI) concentration of the earth samples decreased by about of $18 \%$ (date not shown); this might be caused by indigenous microflora and (or) reducing components present in the soil.

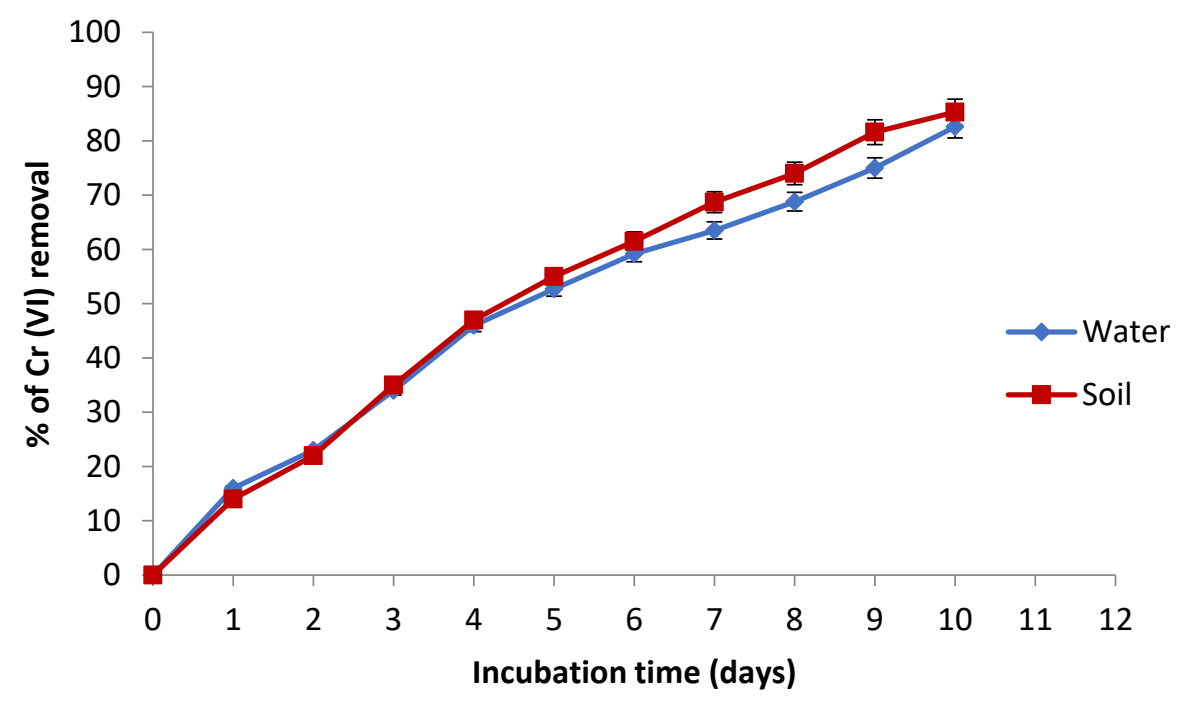

Fig. 5. Removal of $\mathrm{Cr}$ (VI) in industrial wastes incubated with $25 \mathrm{~g}$ of biomass. $28^{\circ} \mathrm{C}, 100$ rpm, $20 \mathrm{~g}$ and $100 \mathrm{~mL}$ of contaminated soil and water, (297 $\mathrm{mg} \mathrm{Cr}$ (VI)/g soil, and $200 \mathrm{mg}$ $\mathrm{Cr}(\mathrm{VI}) / \mathrm{L})$.

The adsorption capacities of Cr (VI) with different biosorbents are showed in Table 1 .

Table 1. Comparison of adsorption capacities of $\mathrm{Cr}(\mathrm{VI})$ with other biosorbents.

\begin{tabular}{llcl} 
Adsorbent & $\mathrm{pH}$ & $\begin{array}{c}\text { Adsorption capacity } \\
\mathrm{mg} / \mathrm{L}\end{array}$ & \multicolumn{1}{c}{ Reference } \\
$\begin{array}{l}\text { Auricularia polytrica } \\
\text { Citrus reticulata }\end{array}$ & $1-2$ & 50 & Zheng et. al., 2014 \\
Litchi chinensis & 1.0 & 50 & Acosta et. al., 2013 \\
Potato peeling & 1.0 & 50 & Acosta et. al., 2012 \\
Russian knapweed & 2.5 & 40 & Mutongo et. al., 2014 \\
Chitosan & 2.5 & 15 & Ghaneian et. al., 2013 \\
& 4.0 & 58.8 & Sobhanardakani et. al., \\
Coconut tree sawdust & 3.0 & 3.6 & Selvi et. al., 2001 \\
Activated carbón & 4.5 & 36 & Cao et. al., 2010 \\
Sugar cane baggase & 2.0 & 13.4 & Sharma and Foster, 1994 \\
Al(OH)CO3 & 7.0 & 60 & Zhong et. al., 2007 \\
Avena sativa & 1.0 & 100 & This work
\end{tabular}




\section{DISCUSSION}

The optimum time and $\mathrm{pH}$ for $\mathrm{Cr}(\mathrm{VI})$ removal by A. sativa biomass were $8 \mathrm{~h}$ and 1.0, respectively. The fruit body of Auricularia polytricha (an edible mushroom, common in China and other parts of the world) had removed 1, 50 and $100 \mathrm{mg}$ of $\mathrm{Cr}$ (VI) per liter after $48 \mathrm{~h}$ at a pH ranging between 1-2 (using $2 \mathrm{~g}$ of bioabsorbent per liter) (Zheng et al., 2014). It has been used powder of potato peelings ( $4 \mathrm{~g}$ of biomass per liter) for the removal of 40 $\mathrm{mg}$ of $\mathrm{Cr}$ per liter (in aqueous solution) at $\mathrm{pH}$ of 2.5 after $48 \mathrm{~min}$ (Mutongo et al., 2014). The removal of $\mathrm{Cr}$ (VI) by the Citrus reticulata shell and by the Citrus paradise shell has been carried out after $30 \mathrm{~min}$ (Acosta et al., 2013) and $70 \mathrm{~min}$ (Acosta-Rodríguez et. al., 2016), respectively. Modified Russian knapweed flower powder $(1.0 \mathrm{~g} / 100 \mathrm{~mL}$ of biomass) was used for removal of 2, 10 and $15 \mathrm{mg}$ of $\mathrm{Cr}$ (VI) per liter at $\mathrm{pH}$ of 1.0 (Ghaneian et al., 2013). Changes in the permeability of unknown origin, could partly explain the differences founded in the incubation time, providing greater or lesser exposure of the functional groups of the cell wall of the biomass analyzed (Ahemad, 2014; Tejada Tovar et al., 2015). On the other hand, it has been reported the ability of the yeast Candida tropicalis to remove $\mathrm{Cr}$ was tested in artificially contaminated soils in a microcosm system to simulate natural environmental conditions, showing reduction of $72.2 \%$ of $40 \mathrm{mg} / \mathrm{L}$ $\mathrm{Cr}(\mathrm{VI})$ (Bahafid et al. 2013). An A. niger strain isolated from a tannery was used in an airlift reactor for the treatment of tanning wastewater, leading to maximum removal efficiency by adsorption of $88 \%$ of an initial Cr (III) concentration of $1300 \mathrm{mg} / \mathrm{L}$ (Sepehr et al. 2012). These results are better than those obtained (removal efficiency of $72 \%$ ) with the same organism using a stirred tank reactor (Sepehr et al. 2012). The use of a consortium of Cr-resistant fungi immobilized in a support material in a stirred tank bioreactor filled with wastewater from a tannery achieved an overall removal efficiency of $99.9 \%$ of the total Cr present.

In conclusion, the biomass analyzed, showed complete capacity of biosorption of $1.0 \mathrm{~g} / \mathrm{L}$ $\mathrm{Cr}$ (VI) in solution at different time of incubation, at $28^{\circ} \mathrm{C}, 100 \mathrm{rpm}$ with $1 \mathrm{~g}$ of biomass, besides this removal the metal in situ (10 days of incubation, $25 \mathrm{~g}$ of biomass), in earth and water contaminated. These results suggest their potential applicability for the remediation of $\mathrm{Cr}(\mathrm{VI})$ from polluted soils in the fields. However, biosorbents may be affected by the high concentrations of these contaminants, interrupting the adsorption process by the biomass. Consequently, the use of biomass does not live; it has become the main subject of research for scientists, being these easily accessible, low cost and with great adsorption capacity. In addition, their physical and chemical properties can be modified by increasing the active sites of sorption. Finally, the oat biomass removal efficiently $\mathrm{Zn}$ (II), $\mathrm{Cu}$ (II), Cd (II) and $\mathrm{Pb}$ (II) (Areco and dos Santos Afonso, 2012; Garcia-Gallegos et, al., 2011), and methylene blue (Díaz-Flores et. al., 2013), and this results confirm the ability of this biomass to be used in heavy metal bioremediation.

\section{CONFLICT OF INTEREST}

The authors have no conflict of interest to declare. 


\section{REFERENCES}

Acosta, I., Coronado, E., Cárdenas, J.F., Tovar, J. \& Martínez, V.M. 2013. Hexavalent chromium removal by Citrus reticulata Shell. Journal of Natural Sciences. 1(1): 29-39.

Acosta-Rodríguez, I., Cárdenas-González, J.F., Moctezuma-Zarate, M.G. Rodríguez-Pérez, A., Enríquez-Domínguez, E., Tovar-Oviedo, J. Martínez-Juárez, V.M. \& Acosta-Nava, M.Z. 2016. Biosorption of Chromium (VI) by Citrus paradise Shell. Journal of Multidisciplinary Engineering Science and Technology (JMEST). 3(6): 5056-5061.

Acosta, I., Sandoval, P., Bautista, D., Hernández, N., Cárdenas, J.F. \& Martínez, V.M. 2012. Bioadsorción de Cromo (VI) por la cáscara de Mamey (Mammea americana L.). Avances en Ciencias e Ingeniería. 3(2):1-9.

Acosta-Rodríguez, I., Martínez-Pérez, R., Cárdenas-González, J.F., Moctezuma-Zárate, M.G. \& Martínez-Juárez, V.M. 2012. Hexavalent Chromium Removal by Litchi chinensis Sonn Peel. American Journal of Biochemistry and Biotechnology. 8 (1): 7-13.

Agarwal, G.S., Kumar, H. \& Chaudari, S. 2006. Biosorption of aqueous chromium (VI) by Tamarindus indica seeds. Bioresource Technology. 97: 949-956.

Ahemad, M. 2014. Bacterial mechanisms for $\mathrm{Cr}(\mathrm{VI})$ resistance and reduction: an overview and recent advances. Folia Microbiologica. 59: 321-332.

Areco, M.M. \& dos Santos Afonso, M. 2012. Biosorción, una opción eficiente y sustentable para la remediación ambiental. Argentina y Ambiente. 579-584.

Bahafid, W., Tahri Joutey, N., Sayel, H., Boularab, I. \& El Ghachtouli, N. 2013. Bioaugmentation of chromium polluted soil microcosms with Candida tropicalis diminishes phytoavailable chromium. Journal of Applied Microbiology. 115: 727-734.

Cao C.Y., Cui Z.M., Chen C.Q., Song W.G. \& Cai W. 2010. Ceria Hollow Nanospheres Produced by a Template-Free Microwave-Assisted Hydrothermal Method for Heavy Metal Ion Removal and Catalysis. Journal of Physical Chemistry C 114: 9865-9870.

Caviedes Rubio, D.I., Muñoz Calderón, R.A., Perdomo Gualtero, A., Rodríguez Acosta, D. \& Sandoval Rojas, I.J. 2015. Tratamientos para la Remoción de Metales Pesados Comúnmente Presentes en Aguas Residuales Industriales. Una Revisión. Revista Ingeniería y Región. 13(1): 73-90.

Cervantes, C., Campos, J., Devars, J.S., Gutiérrez, F., Loza, H., Torres, J.C. \& Moreno, R. 2001. Interactions of chromium with microorganisms and plants. FEMS Microbiology Review. 25: 335-347.

Chen, S., Yue, Q., Gao, B., Li, Q. \& Xu, X. 2011. Removal of Cr(VI) from aqueous solution using modified corn stalks: Characteristic, equilibrium, kinetic and thermodynamic study. Chemical and Engineering Journal.168: 909- 917. 
Dhal, B., Thatoi, H.N., Das, N.N., \& Pandey, B.D. 2013. Chemical and microbial remediation of hexavalent chromium from soil and mining/metallurgical solid waste: A review. Journal of Hazardous Materials. 250-251: 272-291.

Díaz Florez, P.E., Rodríguez Alfaro, A., Alcalá Jáuregui, J.A. \& Rodríguez Ortiz, J.C. 2013. Remoción de azul de metileno en solución acuosa sobre residuos de avena. Revista Internacional de Contaminación Ambiental. 29 (Supl 1): 132.

García-Gallegos, E., Hernández-Acosta, E., García-Nieto, E. \& Acevedo-Sandoval, O. 2011|. Contenido y translocación de plomo en avena (Avena sativa L.) y haba (Vicia faba L.) de un suelo contaminado. Revista Chapingo Serie Ciencias Forestales y del Ambiente. 17(1): 5-118.

Ghaneian, M.T., Dehvari, M. \& Jamshidi, B. 2013. A batch study of hexavalent chromium removal from synthetic wastewater using modified Russian knapweed flower powder. International Journal of Environmental Health Engineering. 2(5): 38-46.

Greenberg, A.E., Clesceri, L.S. \& Eaton, A.D. 1992. Standard Methods for the Examination of Water and Wastewater. American Public Health Association, Washington, DC, USA, 18th edition. 3.58-3.60.

Gutiérrez-Corona, J.F., Romo-Rodríguez, P., Santos-Escobar, F., Espino-Saldaña, A.E. \& Hernández-Escoto, H. 2016. Microbial interactions with chromium: basic biological process and applications in environmental biotechnology. World Journal of Microbiology and Biotechnology. 32: 1-9.

Leyva, R., Bernal, L.A. \& Acosta, I. 2005. Adsorption of cadmium (II) from aqueous solution on natural and oxidized corncob. Separation and Purification Technology.45: 4149.

Lofroth, G. \& Ames, B.N. 1978. Mutagenicity of Inorganic Compounds in Salmonella typhimurium: Arsenic, Chromium and Selenium. Mutation Reseach. 53(1): 65-66.

Mutongo, F., Kuipa, O. \& Kuipa, P.K. 2014. Removal of Cr(VI) from aqueous solutions using powder of potato peelings as a low cost sorbent. Bioinorganic Chemistry and Applications. Vol. 2014, Article ID 973153, 7 pages. http://dx.doi.org/10.1155/2014/973153.

Sag, Y. \& Aktay, Y. 2002. Kinetic studies on sorption of $\mathrm{Cr}$ (VI) and Cu (II) ions by chitin, chitosan and Rhizopus arrhizus. Biochemical Engineering Journal. 12(2): 143-153.

Selvi K., Pattabhi S. \& Kadirvelu K. 2001. Removal of Cr(VI) from aqueous solution by adsorption onto activated carbon. Bioresource Technology 80: 87-89. 
Sepehr, M.N., Nasseri, S., Zarrabi, M., Samarghandi, M.R., \& Amrane, A. (2012) Removal of $\mathrm{Cr}$ (III) from tanning effluent by Aspergillus niger in airlift bioreactor. Separation and Purification Technology. 96: 256-262.

Sepehr, M.N., Zarrabi, M., \& Amrane, A. 2012. Removal of Cr (III) from model solutions by isolated Aspergillus niger and Aspergillus oryzae living microorganisms: equilibrium and kinetic studies. Journal of Taiwan Institute of Chemistry. 43:420-427.

Sharma D.C. \& Forster C.F. 1994. A preliminary examination into the adsorption of hexavalent chromium using low-cost adsorbents. Bioresource Technology. 47: 257-264.

Sobhanardakani, S., Zandipak, R., Bonyadi, M., Parvizimosaed H., Moslemi, M., Tahergorabi, M. \& Hosseini, S.M. 2015. Evaluation of removal efficiency of Cr (VI) ions from aqueous solution using chitosan. Journal of Chemical Health Risks. 5(1): 29-38.

Tejada Tovar, C., Ruiz Paternina, E., Gallo Mercado, J. \& Moscote Bohórquez, J. Evaluación de la biosorción con bagazo de palma africana para la eliminación de $\mathrm{Pb}$ (II) en solución. Prospect. 13(1): 59-67.

Tejada-Tovar, C., Villabona-Ortiz, Á. \& Garcés-Jaraba, L. 2015. Adsorción de metales pesados en aguas residuales usando materiales de origen biológico. Tecno Lógicas.18 (34):109-123.

Watts, M.P., Khijniak, T.V. Boothman, Ch. \& Lloyd, J.R. 2015. Treatment of Alkaline $\mathrm{Cr}(\mathrm{VI})$-Contaminated Leachate with an Alkaliphilic Metal-Reducing Bacterium. Applied and Environmental Microbiology. 81(16): 5511-5518.

Zheng, S., Huang, H., Zhang, R. \& Cao, L. 2014. Removal of Cr(VI) from aqueous solutions by fruiting bodies of the jelly fungus (Auricularia polytricha). Applied Microbiology and Biotechnology. 98:8729-8736.

Zhong L.S., Hu J.S., Cao A.M., Liu Q., Song W.G. \& Wan L.J. 2007. 3D Flowerlike Ceria Micro/Nanocomposite Structure and Its Application for Water Treatment and CO Removal. Chemical Materials. 19: 1648-1655. 